\title{
The Alliance of Community-Owned Water Services in Europe: Opportunities and Challenges Based on the Irish Perspective
}

\author{
Barry Deane * and Brian Mac Domhnaill \\ National Federation of Group Water Schemes, 24 Old Cross Square, H18 NX30 Monaghan, Ireland; \\ brian@nfgws.ie \\ * Correspondence: barry@nfgws.ie
}

Citation: Deane, B.; Mac

Domhnaill, B. The Alliance of

Community-Owned Water Services

in Europe: Opportunities and

Challenges Based on the Irish

Perspective. Water 2021, 13, 3181.

https://doi.org/10.3390/w13223181

Academic Editors: Andrea Guerrini and Giulia Romano

Received: 30 September 2021

Accepted: 1 November 2021

Published: 10 November 2021

Publisher's Note: MDPI stays neutral with regard to jurisdictional claims in published maps and institutional affiliations.

Copyright: (c) 2021 by the authors. Licensee MDPI, Basel, Switzerland. This article is an open access article distributed under the terms and conditions of the Creative Commons Attribution (CC BY) license (https:/ / creativecommons.org/licenses/by/ $4.0 /)$.
Abstract: The foundation of the Alliance of Community-Owned Water Services in Europe (ACOWAS-EU), established during the consultation period for the 2020 recast of the European Drinking Water Directive, has shone a new light on community-owned drinking water supplies (CoDWS). CoDWS are drinking water supplies that are administered, managed, and owned by the local community membership that each supply serves. This paper reviews the presence of CoDWS within the five founding regions of ACOWAS-EU-Austria, Denmark, Finland, Galicia in Spain, and Ireland-and the co-operative model structure that underpins the sector. Although the co-operative structure for CoDWS has been prominent since the mid-20th century (and sometimes even earlier), there is a dearth of research into the sector's importance and existence in an international context. Through a detailed case study, the Irish CoDWS sector (known in Ireland as the group water scheme sector) is analysed in depth, in terms of both its evolution and the opportunities and challenges it faces today. Areas, such as water quality, biodiversity, education, and community-involvement are discussed in particular, providing key learnings that may also be of benefit to the other CoDWS sectors within ACOWAS-EU and further afield.

Keywords: drinking water; community-owned drinking water supplies (CoDWS); co-operatives; community

\section{Introduction}

Water services are defined in Article 2 (38) of the European Union Water Framework Directive [1] as all services that provide for households, public institutions, or any economic activity (a) abstraction, impoundment, storage, treatment, and distribution of surface water or groundwater; (b) waste-water collection and treatment facilities, which subsequently discharge into surface water. Each member state is obliged to monitor the quality of water intended for human consumption (drinking water) in accordance with the European Drinking Water Directive [2]. A recast of the Drinking Water Directive [3] was approved by the Commission on 16 December, 2020, and member states have until January 2023 to transpose it into national legislation. The Drinking Water Directive sets clear limits for a range of parameters, requiring member states to monitor compliance levels in water supply zones and report them annually [4]. Monitoring frequencies depend on the population supplied by the water supply zone. Member states have different approaches to governance arrangements to ensure compliance with the directive, generally assigning specific roles to public bodies or state agencies to monitor and regulate the water service providers for both drinking water quality and economic regulation.

The most recent EurEau report [5] identifies four prevalent management models for water service delivery across Europe-direct public management, delegated public management, delegated private management, and direct private management. The report identified that most European countries have a mix of the first three management models, with a general trend towards public and private delegated management, with the majority of water services being in public (state) ownership. 
For this reason, there has been little recognition of the community-owned water services sector across Europe. In 2011, the World Health Organisation (WHO) defined community-managed supplies in the pan-European region as water supply systems administered and managed via self-responsibility by the community members (for example, co-operatives) who are also the users of the water [6].

The World Bank [7] also recognised the contribution of community-based organisations, summarised particularly in the delivery of rural water services based on the principle of population density. They identified community-based organisations as primary service providers in highly dispersed rural populations, rural villages, and emerging growth centres. While that paper is based on developing countries, the establishment and existence of community-owned drinking water supplies (CoDWS) is recognised.

Although not every European country appears to have CoDWS, there is evidence of their existence, in, at least, Austria, Cyprus, Denmark, Finland, Germany, Ireland, Italy, and Galicia in Spain. However, most European countries do not differentiate between CoDWS and public supplies when monitoring and reporting water quality data in accordance with the Drinking Water Directive, instead separating water supply zones into small (less than 5000 population supplied) and large ( $>5000$ population served) supplies.

The exception to this is Ireland, where the Irish Environmental Protection Agency (EPA) publish two drinking water quality reports annually, one for public supplies and one for private supplies (including CoDWS) [8]. Ireland is also one of the founding members of the Alliance of Community-Owned Water Services in Europe (ACOWAS-EU), which was established in 2018.

This paper reviews the five major European regions that make up ACOWAS-EU, in which CoDWS have a significant presence. A sizeable number of these supplies operate under a co-operative model structure, although few studies to date have been undertaken on CoDWS and/or its co-operative governance structure.

\subsection{The Concept of a Co-Operative}

Co-operatives have been widely used in European countries since the early 1800s, with the establishment of a co-operative movement attempting to address the concurrent labour and social movement issues being experienced at the time [9].

There is evidence of co-operative principles being applied to an established society as early as 1761 [10] in Fenwick, Scotland, where local weavers formed the Fenwick Weavers' Society to sell products at a discounted rate [11]. In 1844, a group of 28 artisans working in the cotton mills established the first modern co-operative business, the 'Rochdale Equitable Pioneers Society,' in Rochdale, England, also known as the Rochdale Pioneers. They are regarded as the founders of the co-operative movement [11].

Promotion of the co-operative model led to widespread use of the structure and principles in the United Kingdom and right across Europe during the 19th century. There are examples of co-operatives being established in countries such as Germany, Denmark, Finland, and Austria throughout the mid-19th century. The primary driver appears to have been the food production and distribution sectors, but also 'services,' including the provision of financial and social services. In Germany, a co-operative model was established by Friedrich Wilhelm Raiffeisen and Franz Hermann Schultz-Delitsch for shoemakers in 1949 using similar principles [12]. Both men were instrumental in the establishment of the community-owned and controlled financial services (which paved the way for the beginning of the credit union movement in Germany in 1862). Co-operatives in Germany have also operated for over 100 years as regional energy utilities, with more than 800 new co-operatives created during the period 1995-2015 [13].

\subsection{The History and Evolution of CoDWS Co-Operatives}

While the co-operative ethos of community owning and sharing of assets, goods and services has been around for well over a century, the use of the structure for water services, and, in particular, drinking water, appears to have only been formally introduced during 
the first half of the 1900s. However, Romano [14] indicated that there is evidence to support the existence of water co-operatives as early as 1500 in south Tyrol, northern Italy where Leonhard von Völs, Lord of Tyrol, established an entity in Fiè allo Sciliar in 1597. In Finland, the first registered water co-operative was established in Pispala, near the city of Tampere in 1907 [15], which resulted in the community not having to travel significant distances to retrieve drinking water in this geographically limited area. Although this first formal water co-operative was established in a suburban area, Arvonen et al. [15] describe how typically CoDWS co-operatives were mostly established in rural areas of Finland, largely by the farming community.

Other early examples of CoDWS co-operatives appear in the upper region of Austria, in the period immediately after World War II. On 26 April 1946, the Upper Austrian Parliament passed a unanimous resolution to establish an umbrella organisation for water service providers including community-owned co-operatives to provide support and guidance to its members [16].

Community water supply co-operatives can also be found in many rural areas of many developed countries, such as Canada (200 co-ops), the United States (3300 co-ops), and South America (15 water co-operatives in Bolivia and 137 in Chile) [15]. Furthermore, in developing economies, such as Kenya, many self-organised water supply projects seem to operate largely using the principles of community-owned water co-operatives [15]. Etongo et al. [17] evaluated community participation and capacity development in water users' committees in relation to community-managed water supply systems in Uganda.

\subsection{CoDWS Co-Operatives Today}

It was not until the mid-20th century that the formal co-operative structure was largely promoted for the provision of CoDWS. This 'co-operative' structure, which forms the basis of the CoDWS governance structure within the ACOWAS-EU member states, was defined by the International Co-operative Alliance (ICA) at its world congress in 1995, as: "An autonomous association of persons united voluntarily to meet their common economic, social and cultural needs and aspirations through jointly owned and democratically controlled enterprise" [18].

The seven principles of a co-operative defined by the International Co-operative alliance (1995) are still employed by the ACOWAS-EU members, i.e., (i) voluntary and open membership; (ii) democratic member control; (iii) member economic participation; (iv) autonomy and independence; (v) education, training and information; (vi) co-operation among co-operatives; and (vii) concern for community.

The Irish CoDWS sector (known in Ireland as the group water scheme sector) will be the primary focus of this paper, including an analysis of opportunities and challenges faced by the sector today and how it may provide key learnings for other CoDWS regions within Europe and further afield.

The co-operative movement in Ireland is particularly popular within the agricultural and rural service sectors, such as the CoDWS sector, with recent statistics indicating that $68 \%$ of community-owned group water schemes affiliated to their representative body, the National Federation of Group Schemes (NFGWS), are structured as co-operatives [19].

Since the turn of the century, there have been significant improvements in Irish CoDWS governance and compliance with drinking water standards [8]. However, unrelated to this, there is evidence in a wider context of a major deterioration in the health of the aquatic environment, both in Ireland [20] and around the world, with a massive loss in biodiversity, and populations are faced with the imminent demise of many more species that were once common in the landscape [21]. The scale of biodiversity loss is so serious in Ireland that, on 10 May 2019, the Oireachtas (Irish national parliament) declared it a national emergency alongside climate change [22].

As loss of habitat through human actions is the primary driver of the biodiversity crisis, and the big question is as follows: how do we halt the further destruction of habitat and encourage the restoration or replacement of habitats that have been either damaged 
or completely destroyed? This paper will explore the role the Irish CoDWS sector is playing-through its drinking water source protection initiatives-in helping to address this crisis.

\section{ACOWAS-EU}

In February 2018, the European Commission published a draft recast of the Drinking Water Directive [23]. Many representative organisations for CoDWS individually expressed their concerns with elements of the proposed directive, with a number of these organisations making individual submissions as part of the initial public consultation process. The situation provided the first opportunity for many CoDWS representative organisations to look outside their domestic regions and see if similar type structures existed in other European countries. Recognising the need for greater communication between community-owned water supplies and their representative organisations-an Alliance of Community-owned Water Services in Europe (ACOWAS-EU) was established in September 2018 as an informal information sharing network between organisations from European countries, representing such services.

OÖ WASSER, an umbrella organisation for water service providers from the Upper Austria region, invited interested organisations and academics to discuss the proposed recast Drinking Water Directive and share concerns and experiences. The meeting was attended by CoDWS representatives from Austria, Denmark, Galicia in Spain, and Ireland. An output from the meeting was a short position paper detailing concerns from a CoDWS perspective, which was signed by the representative organisations present and submitted to the European Commission. Although not present at the meeting, the CoDWS representative organisation from Finland expressed its support.

Subsequent meetings were held in Galicia, Spain, in June 2019, and Ireland in September 2019, where the Alliance agreed on a name, mission, shared vision, and a number of strategic objectives:

ACOWAS-EU Agreed Terms of Reference June 2019

Membership: Membership of ACOWAS-EU is open to all organisations and agencies within the European Union representing collectives of community-owned water supplies on a national or regional basis. Associate membership is open to anyone interested in the community-owned water sector.

Agreed mission: to provide effective representation for community-owned water supplies within the European Union, building a sustainable and resilient European rural water sector by learning from each other, implementing best practice, providing professional service delivery, protection of drinking water sources, effective water conservation, and the consistent delivery of safe and wholesome drinking water supplies.

Shared vision: a sustainable, financially secure, reliable, and efficient community-owned water supply sector within Europe supplying safe and wholesome drinking water on a consistent basis, promoting a co-operative approach to local water service delivery.

Strategic Objectives:

- To provide a collective voice where necessary at the European level, highlighting the values and interests of the sector in water policy matters.

- To learn from member experiences in relation to: provision of quality drinking water services; implementation of effective measures to protect water sources; implementation of effective water conservation measures; governance arrangements; and professional management and service delivery.

While the umbrella organisations mostly represent community-owned drinking water supplies, some also have members involved in wastewater and irrigation service provision. The next section reviews the extent of the CoDWS movement and representative organisations across four specific countries/regions who are members of ACOWAS-EU, with Ireland discussed in depth later in this paper. 


\subsection{Austria}

Large and small municipal utilities serve nearly $70 \%$ of the population in Austria. Co-operatives provide water to $11 \%$ of inhabitants and the remaining $8 \%$ rely on piped self-provision [24]. Altogether, $24 \%$ of Austrians are served by water utilities supplying less than 5000 inhabitants and $66 \%$ are connected to water utilities supplying more than 5000 inhabitants [24].

In total, Austria has approximately 3400 community-owned water co-operatives [24]. While the services provided by these co-operatives are primarily drinking water services, some also provide wastewater services. Some water co-operatives have also been established to provide irrigation and flood defence services. The region with the most abundant number of community-owned drinking water supplies is Upper Austria (1085), but numbers also exist in Salzburg, South Burgenland, and Styria.

\section{Umbrella Organisations with CoDWS Members in Austria}

Umbrella representative organisations were established by the state in four regions, setup to support and assist all water service providers, including CoDWS co-operatives. Each organisation's membership also includes other water-related services, such as wastewater services and irrigation services and a mixture of state and non-state water service-related organisations, including associate members and state representatives.

In 1946, the Upper Austrian State Parliament approved the foundation of an umbrella organisation (known today as OÖ Wasser) for common guidance and support [16]. The organisation has 1983 members (1101 drinking water co-operatives) along with 64 municipalities, the Province of Upper Austria, the Chamber of Agriculture for Upper Austria, several personal memberships and special systems memberships (source: direct communication with OÖ Wasser, 2021). Of the four umbrella organisations, it has the largest number of community-owned drinking water supplies using the co-operative governance structure.

Three other regions of Austria have also established umbrella organisations. While the objectives and goals of these umbrella organisations appear to be similar to OÖ Wasser, their membership represent fewer community-owned drinking water supplies and more municipal-owned and operated services relating to water. Every year, a meeting is held between all umbrella organisations, which provides an opportunity to network, discuss issues and identify solutions to improve governance, supply, and representation (source: direct communication with OÖ Wasser, 2021).

IG Wassergenossenschaften Südburgenland (IGWS) was founded in the year 2000. Currently, IGWS estimates that only about 120 of the 300 original CoDWS co-operatives in the districts of Jennersdorf, Güssing, and Oberwart are in existence today, providing around $10 \%$ of the population in this region with drinking water. The organisation is now 20 years in existence and has 47 CoDWS co-operative members [25].

Dachverband Salzburger Wasserversorger (DSWV) was established in October 2003 in the state of Salzburg by order of parliament. There are over 680 water supplies in Salzburg [26], with more than 379 represented by DSWV, and 307 represented CoDWS are structured as co-operatives (source: direct communication with DSWV, 2021).

Steirischer Wasserversorgungsverband (StWV) was established in Styria in 1988 under similar circumstances. Its membership in 2017 consisted of 78 organisations, including 17 community-owned water co-operatives [27].

Besides the representation of their members, these associations offer members a range of services and support to assist them in implementing best practices and meeting their legislative obligations.

\subsection{Denmark}

The Danish water supply is highly decentralised, with approximately 120 drinking water and sewerage utilities organised as companies that supply more densely populated areas, while private CoDWS co-operatives supply mostly rural areas and villages [28]. 
CoDWS in Denmark are organised as co-operatives and the Association of Danish Water Supply, Danske Vandvaerker, is their umbrella organisation. Danske Vandvaerker provides representation and assistance to its members including advice, training courses, network management, and political advocacy to promote a safe and efficient water supply [29]. Danske Vandvaerker has approximately 1800 CoDWS members in Denmark accounting for approximately $40 \%$ of the total amount of drinking water abstracted and supplying close to two million people [29]. The remainder of the population receives services from municipally owned and operated supplies or individual supplies. The number of households connected to a community-owned drinking water co-operative is reported to vary from 10 up to 20,000 households with the average size of approximately 400-600 households. They typically supply villages, small towns, or a number of rural households [29].

Danske Vandvaerker reports that its members consist of both privately sourced and publicly sourced CoDWS. By becoming members of Danske Vandvaerker, members are entitled to legal advice of any kind regarding water supply, insurance, access to conferences and expos, training, advice, and assistance (source: direct communication with Danske Vandvaerker, 2021).

\subsection{Finland}

There are reported to be over 4000 co-operatives in Finland, having almost 7 million memberships out of a population 5.5 million [30]. This suggests many citizens are members of multiple co-operatives and according to Pellervo [30], approximately $80 \%$ of Finns are members of at least one co-operative. It is estimated that there are over 1500 of these co-operatives supplying drinking water to $13 \%$ of the population, mainly in rural areas [31], with water co-operatives established and shaped according to local areas need and available resources [15].

Unlike in other European countries, a significant amount of research on CoDWS in Finland has been undertaken. Arvonen et al. [15] report that CoDWS operated largely as co-operatives, the first of which was established in Pispala, near Tampere in 1907. Its establishment was again as a result of people having to retrieve drinking water from a distant water source [32].

The publication, 'Features of Water Cooperatives: A Comparative Study of Finland and Kenya,' identifies the evolution of CoDWS co-operatives in Finland, summarised in Table 1 below.

Table 1. Development phases of Finnish Water Cooperatives [15].

\begin{tabular}{|c|c|c|c|c|c|}
\hline \multirow{2}{*}{ Period } & 1 & 2 & 3 & 4 & 5 \\
\hline & 1900-1950 & 1950-1970s & 1975-1990s & 1990s-Today & 1950s-1960s \\
\hline $\begin{array}{l}\text { Characteristics of } \\
\text { water cooperatives }\end{array}$ & $\begin{array}{l}\text { Built without } \\
\text { financial support. } \\
\text { Willingness to } \\
\text { continue as } \\
\text { independent } \\
\text { cooperatives } \\
\text { is strong }\end{array}$ & $\begin{array}{l}\text { Stronger role of } \\
\text { municipalities and } \\
\text { state-Loans and } \\
\text { grants for } \\
\text { organizing rural } \\
\text { water services. }\end{array}$ & $\begin{array}{l}\text { Mostly in } \\
\text { rural areas. } \\
\text { Actively } \\
\text { encouraged and } \\
\text { supported by } \\
\text { municipalities. } \\
\text { Less independent } \\
\text { than earlier } \\
\text { cooperatives- } \\
\text { Weaker ownership } \\
\text { passive members. }\end{array}$ & $\begin{array}{l}\text { Mostly in } \\
\text { rural areas. } \\
\text { Sanitation. } \\
\text { External pressure } \\
\text { significant for } \\
\text { setting up. } \\
\text { Often planned } \\
\text { as temporary } \\
\text { solutions. }\end{array}$ & $\begin{array}{c}\text { Larger water } \\
\text { cooperatives. } \\
\text { Operate in } \\
\text { midsized towns, } \\
\text { very similar to } \\
\text { municipal utilities, } \\
\text { however, nonprofit } \\
\text { based. } \\
\text { Employees Skilled } \\
\text { labour }\end{array}$ \\
\hline
\end{tabular}

These phases demonstrate how the sector evolved, established initially out of necessity with heavy reliance on volunteerism, moving to a model influenced by policy such as various funding incentives, and ultimately progressing towards larger co-operatives operated and managed in a professional manner similar to small utilities. 
Takala et al. [33] report that water co-operatives in Finland are quite diverse in terms of corporate form, size, services provided, knowledge and technical expertise, economic situation, infrastructural state, and maintenance provided. This diversity is reportedly driven by differences in individuals, membership needs, environmental and economic circumstances with CoDWS being shaped according to the needs of members and available resources [33].

Suomen Vesihuolto-Osuuskunnat Ry-The Association of Finnish Water Co-Operatives

SVOSK is an umbrella body formed to represent the interests of CoDWS co-operatives across Finland. Its register includes 1316 registered water co-operatives [15]. The Association was established in 2009 to serve the interests of water co-operatives across the country, particularly drinking water supply and water sanitation. SVOSK is a member of the Pellervo Society, which is an umbrella organisation for all Finnish co-operatives and a forum for co-operative activities.

SVOSK acts as a nationwide non-profit representative and development association for water co-operatives and water associations (SVOSK defined the term 'Association' as referring to a group of people organised for a joint purpose structured as a partnership, co-operative, or limited company). Its membership consists of both privately sourced and publicly sourced community-owned drinking water supplies. Its aim is also to strengthen skills and promote co-operation between CoDWS and public water sectors, promote the quality and safety of domestic water, promote equality between community-owned and local government-owned water utilities. It promotes knowledge exchange between members, and provides advisory and training services [34].

\subsection{Galicia, Spain}

According to Sanchez [35], water services in Spain are provided by either public authorities, private companies, public-private consortiums or municipal services. In Galicia, users rely mostly on private companies, which represents almost double the ratio compared to national scale [35].

The autonomous community of Galicia is located in the northwest of Spain. Sanchez [35] reports that rural areas are most likely to be supplied by decentralised CoDWS. According to the Life Rural Supplies project, more than 580,000 people get their drinking water through, what it describes as 'autonomous solutions' - either through CoDWS or private wells with the remaining population served by municipal supplies [36]. In addition Campo Galego estimates that in Galicia there may be more than 5000 community catchments [37], all indicating a significant CoDWS sector.

\section{Comunidade Xeral De Augas De Galicia}

Comunidade Xeral De Augas De Galicia (COXAPO) is an association of communityowned water supplies in the Pontevedra province of Galicia. COXAPO represents a total of 165 community-owned water supplies across the region, representing 20,471 houses (71,648 population). COXAPO was established in Tomiño, in 2008, following a water conference in Estás, when several community-owned water supplies joined together to seek recognition and support for their members from the regional government [38].

The organisation represents the sector at local and regional levels, contributing to water policy, working with governing bodies and advising and supporting its members to ensure compliance with the Drinking Water Directive. The association has developed several low-cost treatment solution models along with establishing a continuous water quality monitoring system for members. It actively promotes water quality and conservation, having developed procedures and template manuals for members. COXAPO reports that all members are required to have a legal structure in place. The organisation assists CoDWS in this regard and ensures a co-operative ethos underpins their operations (source: direct communication with COXAPO, 2021). 


\subsection{Existence in Other European Countries and Beyond}

While there is further evidence to support the existence of community-owned water supplies utilising the co-operative structure and ethos in other European countries and jurisdictions, they will not be explored further in this paper. Only limited research on the sector has been completed to date; however, it appears that many CoDWS continue to operate successfully independent of each other and the state.

Pietilä et al. [39] directly reference the existence of water co-operatives elsewhere in Europe, including Germany and Italy. Romano [14] identified approximately 150 established water co-operatives in Germany and more than 80 community-owned water supplies in South Tyrol in Italy, as well as evidence of similar type structures internationally. The absence of any representative organisation in Italy is noted.

\section{The Community-Owned Group Water Scheme Sector in Ireland}

The formation and the evolvement of the co-operative movement and the establishment of the community-owned group water scheme sector in Ireland is being used as a case study in this paper. This case study explores the early development and evolution of the group water scheme (GWS) sector, the formation of the National Federation of Group Water Schemes (NFGWS), and promotion of the co-operative structure to improve governance arrangements. How water quality issues (identified in the 1990s) were overcome is also explored; thus, transforming the sector into its current position.

\subsection{Emergence and Early Establishment}

The co-operative movement had a transformative effect on the economy of rural Ireland in the latter years of the 19th century [40]. The Irish economy was struggling in the aftermath of the famine and land reform, and a few visionaries (including Horace Plunkett, RA Anderson, George Russell, Lord Monteagle, and Rev Tom Finlay) were instrumental in establishing the Irish Agricultural Organisation Society in 1894, later renamed the Irish Co-operative Organisation Society in 1979. The number of co-operatives grew from 33 in 1894 to 1114 societies by 1920 [41]. The creameries and agricultural societies were the first to be established but this was followed by the setting up of Agricultural Credit Co-operatives. Today, Irish co-operatives and their associated companies have $>150,000$ individual members and 12,000 employees in Ireland, with 12 co-operatives each generating a turnover in excess of EUR 100 million [42].

The model has proven to be of value to rural communities in providing a framework within which communities can collectively address issues of peripherality and underdevelopment, particularly in the case of community owned group water schemes. The adoption of the co-operative model by the wider community-owned rural water sector commenced on 26 June 1973, when two newly formed group water schemes-Killasser GWS and Menlough GWS - were registered as 'Societies' under the Industrial and Provident Societies Act. Their establishment started a gradual move towards the co-operative model becoming the prevailing corporate structure in the sector. This structure was a natural fit, given the sector's prioritisation and promotion of open and democratic member-participation, leading to accountable management grounded in a rights-based approach.

Although the availability of a water supply was a determining factor in the location of suitable sites for co-operative creameries in Ireland in the late 19th and early 20th centuries, neither rural food processing facilities nor the dairy farms supplying them had access to a municipal water supply [43]. The absence of communal piped water supplies would remain a fact of life in rural Ireland until the 1960s and 1970s with the construction of regional public supply networks and adoption of the group water scheme model where regional mains were unavailable. Until then, for most families and businesses, potable water was carried from the nearest available spring well or from a surface water source, a dug well or rainwater collected from the roofs of buildings.

Following the government decision to expand the provision of electricity to rural areas (which began in 1946), the argument for the construction of communal piped rural water 
supplies was raised [44]. To address the situation where only $3 \%$ of rural households were on a communal water supply, and just one in eight had a piped supply, a three-pronged approach was envisaged under the strategy, which included (i) the provision of regional schemes operated by the Sanitary Authorities; (ii) the provision of group schemes by local communities where reliable local sources were available; and (iii) the provision of piped water by individual householders where neither of the other approaches were feasible.

A model upon which the group water scheme sector would be built had already been established during the late 1950s in a rural area in the east of Ireland, outside Blessington, County Wicklow. This was championed by many organisations including the Department of Local Government as the appropriate solution where it was not feasible to provide a regional supply. Campaigns, such as the Turn on the Tap campaign, launched by the Irish Countrywomen's Association in collaboration with the ESB, and the development of a short promotional film Water Wisdom by the Department of Local Government further promoted the model [44]. After a spurt during the early years of the decade, the rate of construction appears to have declined in the late $1960 \mathrm{~s}$ and $42 \%$ of rural households still lacked a piped water supply in 1971.

Entry to the EEC in 1972 proved a defining moment in the development of communal water supplies in rural Ireland [45]. Farm organisations and dairy co-operatives began actively promoting the campaign for rural water and took a lead role in the formation of group schemes, encouraging their members to provide sources (and access to sources) as well as sites for pumphouses and reservoirs. As a result, the sector flourished in the 1970s, with all but a few of the privately sourced schemes having completed construction by the early 1980s.

Most early group water schemes were formed in the groundwater zones of the east and south of Ireland; a spring or borehole providing a supply to communities within a defined geographic area [46]. As the sector expanded into the 'surface water' zones in the 1970s, schemes tended to be much larger than previously, as predominantly lake sources provided natural raw water reservoirs. In addition, the hilly topography of the border counties and parts of the west of Ireland facilitated gravity feeding a water supply to a much wider geographic area. Distribution networks were provided to service hundreds of dispersed rural dwellings.

In terms of size, group water schemes range from as few as two houses to a small number that supply well in excess of 1000 households [47]. There are approximately 300,000 citizens supplied by the community-owned group water scheme sector today, or just over $6 \%$ of all households in the jurisdiction [48]. The scale of the publicly sourced GWS sector (i.e., schemes owning the distribution network, but receiving treated water from a municipal supply) has always been more difficult to determine with any degree of certainty, but based on returns from EPA reports [49], approximately $2 \%$ of the Irish population is currently on regulated publicly sourced GWS supplies.

Without state support and active supervision, weaknesses inherent in the GWS model began to manifest during the 1980s and 1990s, such as lack of effective co-ordination/management structures, lack of appropriate treatment, and lack of financial resources. The absence of a central organisation to represent group water schemes and to provide training and mentoring meant that individual supplies were isolated from one another and did not have the benefit of mutual learning, knowledge transfer, and sharing of practical experience.

Drinking water quality reports published by Ireland's Environmental Protection Agency (EPA) from the early 1990s carried results of all communal supplies, making Ireland one of only three countries in the European Union to include community-owned supplies at the time [50]. The EPA results attested to widespread non-compliance with microbiological parameters within the sector, with a sizeable majority of schemes failing to meet the standards for faecal indicators, such as Escherichia coli (E. coli). 


\subsection{Formation of the National Federation of Group Water Schemes}

In December 1996, the Irish Environment Minister, Brendan Howlin, announced the abolition of charges for domestic consumers on water supplies operated by municipal authorities. The group scheme sector-providing an estimated $25 \%$ of rural water supply at that time-was excluded from the announcement. In response, group water schemes began talking to one another at a local, regional and then national level with meetings and consultations held to determine how the sector should respond to its exclusion from State supports.

In February 1997, the NFGWS was established and a National Executive put in place. The primary objective of the new umbrella organisation was to secure equality of treatment, ensuring that those it represented received their full entitlement to the financial supports already conceded to their fellow citizens in urban areas. In the early stages of its development, the NFGWS was, therefore, a campaigning organisation, exerting pressure on government on the issue of financial supports and threatening to put forward candidates for election to Dáil Éireann unless the sector's grievances were addressed [51].

Far from meeting resistance to its demands, the NFGWS found that government and civil servants were receptive, welcoming the NFGWS as a vehicle through which it could address the issue of widespread parametric non-compliance in GWS supplies. The need for action intensified following confirmation that several members of one group water scheme in the northwest of Ireland (Ballycroy GWS, County Mayo) were taking a case to the European Commission, accusing the Irish State of failing in its obligation to comply with the Drinking Water Directive [52]. As early as October 1998, the Commission wrote to the Irish government setting out the strong case being made against it. This was the context in which a Rural Water Programme (RWP) was negotiated between the NFGWS and the Department of the Environment.

The agreement reached in 1998 established a framework for tackling problems in the rural water sector. This included the establishment of a Ministerial advisory body titled the National Rural Water Monitoring Committee (NRWMC), which would include senior civil servants from the Minister's Department, representatives of the municipal authorities and rural stakeholders including the NFGWS. Day-to-day responsibility for overseeing the sector was transferred from central government to the municipal authorities whose task would be to administer the capital funding and an operational subsidy for group water schemes, both of which were key elements of the RWP.

In terms of its strategic objectives, the programme aimed to protect public health by ensuring compliance with the Drinking Water Directive while pursuing a planned approach to investment, ensuring best practice in all aspects of the management and operation of rural water schemes while sustaining the rural environment and promote economic development. The principle of partnership between the voluntary group water sector the Department and local authorities was essential, with local authorities required to assist in the effective administration of the devolved rural water programme [50].

As a practical consequence of the agreed partnership framework, the NFGWS quickly evolved from a campaigning to a negotiating body that would collaborate with other rural water stakeholders, including municipal authorities and central government.

The formation of the NFGWS as a co-operative society in 1997, acted as the catalyst for a major expansion in the numbers of existing schemes reorganising as co-ops. A total of f54 of the 403 schemes affiliated to the NFGWS in 2020 had already adopted co-operative status prior to the formation of the NFGWS, whereas hundreds registered in the years afterwards. Growth in the number of co-operatives within the sector was chronicled in the NFGWS's Annual Reports from 2002 until 2010. In its Annual Report for 2020, the NFGWS revealed that, of affiliated schemes, 275 were registered co-operatives, 83 trusteeships, 43 companies, 1 association, and 1 for which its corporate status was unclassified [19].

Internally, the NFGWS set about putting in place the structures required to effectively carry out its remit. The years 2001 and 2002 saw the implementation of 35 organisational recommendations contained in a consultancy report drawn up by the co-operative umbrella 
body, ICOS [53]. Their implementation heralded an increasingly professional approach in terms of the internal management of the NFGWS and its working relationship with external organisations.

This dominance of the co-operative model in Ireland's GWS sector was driven by the NFGWS Board, management and staff precisely because it best reflects the fact that schemes (regardless of corporate status) are owned by their members, each member having an equal say in the strategic management of their community asset. As a further example of its focus on schemes as community entities, the NFGWS developed a Charter of Rights and Responsibilities for the members of group water schemes, the adoption of which became a condition for drawing down the operational subsidy.

\subsection{Transformation of the Irish GWS Sector}

An adjudication by the European Court of Justice issued on 14 November 2002 (Case C-316/00) ruled against Ireland for failing to properly implement the Drinking Water Directive. It found that group water schemes must comply with the same onerous quality standards demanded of a municipal water supply and, furthermore, that the state must ensure that this standard was achieved by all water providers under the Drinking Water Regulations (i.e., those supplying more than 50 people or smaller supplies with a social/commercial connection) [54].

In light of the ECJ's judgement, the initial RWP upgrade strategy of piloting new treatment technologies and their application on a scheme-by-scheme basis was set aside, given the clear need for an approach that would deliver change within a shorter timeframe. The scale of the challenge was evident from an annex to the ECJ judgement listing 453 group water schemes. A further 276 non-compliant schemes were subsequently identified, making a total of 729 . Even with the removal from the list of 145 schemes that had already connected to public supplies, there were 584 schemes to be upgraded.

The new strategy agreed by the NRWMC, Action Plan for Rural Drinking Water Quality 2003-2006, determined that the most economically advantageous upgrade solution would be pursued for schemes seeking capital support to upgrade. For many-particularly those relying on surface waters - this meant agreeing to become part of a 'bundle' in a Design Build Operate (DBO) projects in which a professional water services provider would design and operate a treatment process capable of delivering safe and wholesome drinking water over a 20-year contract period. By 2012, when the final DBO bundling contract began its operational phase, 219 group water schemes incorporating more than 47,000 households had been upgraded via this plank of the strategy. Connection to public mains/taking-in-charge, the preferred option in the agreed NRWMC strategy for noncompliant schemes that were close to municipal distribution networks, meant the loss of identity/sovereignty for the schemes involved, resulting in considerable resentment and opposition that was only overcome through NFGWS intervention, and the fact that little or no financial contribution was expected from the schemes involved. Since agreement of the Action Plan in January 2003, some 200 privately sourced schemes were connected to public mains. Improved disinfection systems (and occasionally filtration processes) have been installed on some 200 stand-alone schemes under the Rural Water Programme. However, compliance issues persist due, in part, to the purely voluntary management of many such schemes [8].

The capital programme, costing more than EUR 1 billion did not end at water treatment. There was a major investment in other water services infrastructure including reservoirs and distribution pipes and fittings. Grant-aid covered $85 \%$ of these costs, with the schemes contributing the $15 \%$ balance. As part of this network upgrade strategy, the NFGWS argued for (and secured funding towards) universal metering of all GWS connections, an investment that has contributed to a substantial reduction in daily water demand across the sector, with add-on benefits for water abstraction, treatment, and distribution [47]. 
Under the NRWMC Action Plan, the NFGWS required the recruitment of additional regional development officers and an increased emphasis on training, mentoring, and the dissemination of educational/information materials. Apart from encouraging schemes to consider an upgrade strategy that may not have been their preferred option, this engagement was important for another reason; under the RWP, the State agreed to provide an operational subsidy in addition to capital supports, but there was no automatic entitlement to subsidy. Rather, terms and conditions were introduced, aimed at encouraging schemes to adopt best management practice, especially in terms of delivering a quality water supply. Capacity building was, therefore, a core element of the RWP.

NFGWS strategy is to rationalise clusters of such schemes with a view to putting in place paid management (to achieve compliance with the parameters under the Drinking Water Directive) and to better provide for their sustainability as community-owned businesses.

The Charter of Rights and Responsibilities developed by the NFGWS in 2000 was key to recognising the individual and collective rights and responsibilities of members of group water schemes, while it built on the concept of shared responsibility and set standards for governance and service. This, along with the development and adoption of the Group Water Scheme Co-operative Model Rules by individual schemes, greatly helped improve local governance arrangements.

\section{Discussion-Future Challenges and Opportunities for CoDWS}

Despite improvements in the structure and operation of CoDWS since its inception, challenges still exist, from a combination of environmental, social and economic perspectives. However, hand-in-hand with such challenges are opportunities for CoDWS, which are discussed based on the Irish experience and are considered relevant across any jurisdiction.

\subsection{Water Quality}

As described earlier, national drinking water quality data is not reported specifically for CoDWS, with Ireland being the exception. While limited water quality data are available for some individual CoDWS (either through individual CoDWS or umbrella organisation websites), published national drinking water quality results differentiate water supply zones in terms of volume of drinking water supplied with large supplies (supplying $>1000 \mathrm{~m}^{3}$ per day or $>5000$ people) and small supplies (supplying $<1000 \mathrm{~m}^{3}$ per day or $<5000$ people [55]. Using the principle that CoDWS are generally smaller that municipally owned supplies, data from the European Commission Synthesis Report on the Quality of Drinking Water in the Union examining the member states' reports for the 2011-2013 period was reviewed for the other four regions part of ACOWAS-EU.

Austria has ample high-quality groundwater resources [56]. Given the good quality of the raw water, treatment is minimal, with the use of UV disinfection common, along with only basic filtration and $\mathrm{pH}$ correction if required. A high percentage $(85.9 \%)$ of reported small water supply zones was in full compliance with the quality requirements in the Drinking Water Directive during the 2011-2013 period [57].

The Danish drinking water supply is based entirely on groundwater, needing only minimal treatment with aeration, $\mathrm{pH}$ adjustment and filtration [58]. Data from the European Commission Synthesis Report on the Quality of Drinking Water 2011-2013 for Denmark demonstrated a moderate percentage $66.3 \%$, or 1374 , of small water supply zones was in full compliance with the drinking water quality requirements [57]. However, some regions do appear to be experiencing pressure on those resources. Groundwater quality in some areas appears to be under threat from nitrates and pesticides pollution and salt water from rising sea levels [59].

CoDWS in Finland supply water from a mixture of surface and groundwater sources. The Finnish Institute for Health and Welfare estimates that $42 \%$ of drinking water comes from groundwater, $38 \%$ from surface water, and $20 \%$ from artificial groundwater (shallow wells possibly influenced by surface water) [60]. Data from the European Commission 2016 Synthesis Report on the Quality of Drinking Water in Finland for the 2011-2013 period 
reported that a relatively low percentage (59.4\%) of the small water supply zones was in full compliance with the drinking water quality requirements of the Drinking Water Directive [57]. While sample compliance for microbiological parameters was relatively high, indicator parameters caused a high level of non-compliance especially iron (9.8\%) and manganese (7.5\%) [57].

Surface water is the most commonly used drinking water source in Galicia, representing between $58 \%$ and $76 \%$ of drinking water [35]. This represents a challenge for CoDWS, as treatment of surface water sources is significantly more challenging than groundwater sources. However, according to the Sanchez study [35], where 10 water quality parameters were assessed across the members of COXAPO, the most significant exceedance was the occurrence of low $\mathrm{pH}$, with the remaining parameters being largely in compliance. While microbiological parameters were not monitored as part of that study, COXAPO acknowledge that drinking water quality in community-owned supplies needs to further improve, and is working with its members to address issues. Sanchez [35] also recommends the need for more extensive sampling and monitoring of water quality across the region.

In most cases, the provision of drinking water in full compliance with the Drinking Water Directive appears to be more challenging for smaller water providers. The majority of CoDWS fall into the category of smaller supply zones. We also know that many CoDWS are reliant on volunteer boards to assist with the day-to-day operations.

The need for effective water treatment systems and professional water services providers for rural communities to protect public health has been one of the main drivers in the steady improvement in parametric compliance across the Irish group water scheme sector. Whereas nearly 600 schemes had tested positive for faecal contamination at the turn of the millennium in Ireland, 17 schemes had similar failures in 2019, while compliance with chemical and physical parameters is now close to $100 \%$, despite a noted rise in nitrate levels in some groundwater zones [8]. Problems persist on a small minority of schemes that have yet to complete treatment upgrades, have inadequate treatment or are otherwise deemed to be at risk. These supplies are the main focus of capital investment under Measure 2 of the current three-year Multi-annual Rural Water Programme 2019-2021, and they will remain a priority until their problems are resolved [61]. Learning from the Irish experience, continued investment in appropriate treatment facilities and professional management systems is therefore essential for CoDWS on an ongoing basis to ensure compliance and to protect public health.

\subsection{Requirement of Ongoing Investment}

From discussions among ACOWAS-EU members, the experience has been similar in that the original construction of CoDWS relied heavily on volunteerism and 'good will' to keep costs to a minimum. This is particularly so in the Irish context, where members contributed by providing materials and labour to facilitate construction [44]. Once constructed, operational costs were generally divided among members/shareholders, with many schemes democratically agreeing and implementing charging systems for the services supplies. These charges were mostly in the form of flat rate charges initially, but with the installation of consumer meters over the past 20 years particularly, charges have largely migrated to a rate per cubic metre of water supplied.

Operational costs are normally recovered from the membership in most situations. In Ireland however, the abolition of domestic water charges was conceded prior to an election in Ireland in 1996, on foot of a threat to a government seat from an "abolish water charges" candidate [62]. Despite attempts to reintroduce domestic water charges in 2016 [63,64], the Oireachtas returned to funding domestic water services from within exchequer funding, with charges only applied to excess usage and non-domestic water [65]. In order to ensure equity for the community-owned group water scheme sector in Ireland, an operational subsidy is available to community-owned drinking water supplies towards the operational costs of supplying domestic water [66]. 
With significantly more emphasis placed on the protection of human health since the introduction of the Drinking Water Directive in 1998, many supplies have had to invest in sophisticated treatment systems to ensure that the water being supplied is wholesome, clean and compliant with the parameters set out in the directive. Their primary objective has evolved from the simple provision of piped water supplies to the provision of a product that is safe and wholesome to drink [67]. This has been (and will remain) the primary directive of all community-owned drinking water supplies.

Due to significant underinvestment in the sector for prolonged periods in the past, it is now clear that ongoing capital investment in infrastructure is required on a regular basis and needs to be budgeted for. While the membership contributes towards both capital and operational investment needs, given the privately owned nature of supplies, there is a legitimate question as to whether the state should also support such supplies, due to the public service they provide, and to ensure the quality of that service is sustained into the future. State financial support will greatly depend on water policy within individual member states, which varies considerably across countries and regions. For example, the Irish community-owned group water scheme sector is in receipt of significant state support due to current government policy, while in comparison, financial support in Finland from the state is quite limited.

The level of ongoing investment needed also varies considerably depending on source of water used (groundwater or surface water) and the size and scale of the supply network. For example, a small community-owned supply using a medium-quality surface water source can be extremely expensive to operate and maintain in comparison to a large supply using a good quality groundwater source. What is clear, in either case, is that ongoing capital and operational investment by supplies is needed. Any repeat of previous failures to invest adequately in water services will have long-term implications for competitiveness, economic growth and quality of life [68].

Besides addressing the deficits in water treatment, ongoing capital investment under the Rural Water Programme in Ireland has resulted in the delineation of catchments on all GWS sources, the development of boreholes and source abstraction points, water storage facilities, pipelines, boundary boxes, meters, valves and fittings, and a wide range of monitoring systems. These investments have had a major impact on the reduction of water loss across the GWS sector, thereby ensuring the more effective operation of treatment systems and reducing the operating costs of schemes [50].

Capital and operational support towards CoDWS varies considerably between jurisdictions represented in ACOWAS-EU. Regardless of where the finance is derived, individual supplies need to ensure they adequately budget for their specific operational and capital investment needs by setting realistic charging policies for water.

\subsection{Governance in Ireland}

As already discussed, the community-owned drinking water sector was largely established out of a basic need for piped drinking water supplies in rural areas where the state was unable to supply such a service. Most CoDWS relied on volunteers to establish and run the entities typically drawing upon experience. While co-operatives are governed by a Board, at the core of each co-operative is generally a small group of very committed members who, given the small scale and lack of human resources within these co-operatives, are fundamental to keeping them going operationally [69].

The employment of professional managers and caretakers, where it is viable to do so, to manage and operate community-owned drinking water supplies on behalf of voluntary boards, is actively promoted by the NFGWS in Ireland. One of the challenges faced by community-owned water supplies can be their size, with many supplies being quite small (circa 100 domestic connections) [46]. This poses real challenges, in terms of raising finance, spreading operational costs, implementing professional management and administration systems, etc. Pooling resources between neighbouring supplies can result in larger economies of scale, helping to ensure the long-term sustainability of the 
sector as well as helping to improve overall performance. From the Irish experience, this is particularly the case, as outlined earlier in this paper. The potential to physically join (amalgamate) individual neighbouring schemes can be challenging in terms of securing agreement from members and funding to complete the work, but, if feasible, these solutions provide greater economies of scale, establishing more robust economically sustainable supplies. In Ireland, as part of the Design Build and Operate upgrading programme in the early 2000s, a total of 121 privately sourced group water schemes from around the country were amalgamated into 38 new schemes [70]. These 38 community-owned supplies are thriving today, providing an excellent service to their members and are financially secure for the future.

There is considerable potential for rationalisation and amalgamations between small, stand-alone schemes where as a basis for introducing long-term and effective management of their water supplies. Where individual supplies are not close enough to physically amalgamate, 'rationalisation' can be considered where individual schemes (co-operatives or other) agree to merge to form one new co-operative, to carry out all functions of individual supplies. While there is no physical connection between supplies, rationalisation enables the pooling and sharing of resources, providing greater economies of scale for operational functions as well as minimising duplication in governance and administration [70]. Several rationalisation projects have been successfully implemented in Ireland and the NFGWS see great potential in this governance model, particularly for smaller more dispersed schemes where the employment of a professional manager is currently not viable.

Those familiar with co-operatives believe the full potential of the co-operative business model is yet to be realised in the Irish context and that some key issues such as member engagement and loyalty, government policy, co-operation among co-operatives, awareness, and education will be key to realising this potential [71]. A new Co-operative Act has been in gestation in Ireland for a few years, and commentators have noted that a new Industrial and provident Societies Act will help maintain the required level of governance and promote development of the co-operative sector, particularly if it delivers clearly defined directors' duties, modernised enforcement procedures, an appropriate audit exemption that does not undermine democratic, transparent oversight of the running of co-operatives, and helps to dispel the misconception that co-operatives are dated and archaic [72].

\subsection{Representation and Mentoring Support}

Having an organisation to represent, advise, and support the sector has proved critical in most jurisdictions. Even with the introduction of improved professional management and governance structures, volunteer boards play an essential role in directing and overseeing activities and have important legal responsibilities as directors under the Drinking Water Directive, health and safety legislation, employment legislation, financial legislation etc. It is imperative that proper mentoring and training services are therefore available to both co-operative boards and their employees. The supporting role that representation organisations throughout the ACOWAS-EU regions play in promoting best practice and ensuring proper governance arrangements are in place is essential. The availability of specific technical advice and information on water treatment, water quality monitoring, maintenance of pipe network infrastructure, etc., is also imperative. The established representative organisations appear to be largely providing (either directly or indirectly) these training and mentoring services through established and trusted knowledge exchange networks.

Many of the representative organisations discussed in this paper provide opportunities for members to attend network meetings, receive further education through specific training courses. Field trips and excursions are regularly organised offering knowledge exchange opportunities. Three of the representative organisations provide insurance with two offering group purchasing services as well as consultancy services. All organisations keep members informed of the latest developments through regular contact via website and newsletter publications. 
Besides providing services to members, one significant advantage of representative organisations is the conduit it provides for a collective voice. In advance of the establishment of the NFGWS in Ireland, group water schemes operated very much on an individual basis with little or no contact between schemes. The establishment of the NFGWS not alone provides the sector a democratic structure to enable a collective voice when dealing with government or third parties; it also provides a local and regional network for knowledge exchange among members.

There is significant potential for ACOWAS-EU to provide a similar network and collective voice for the CoDWS sector at a European level. The monitoring frequencies and suite of monitoring parameters in the initial drafts of the recast Drinking Water Directive would have been extremely onerous for CoDWS and the establishment of ACOWAS-EU allowed the sector to highlight these concerns. The subsequently published recast Directive, and its risk-based monitoring approach, is much more manageable for CoDWS.

Given how this collective voice may prove to be an important vehicle for the sector into the future, consideration should be given to formalising the Alliance if thought appropriate by the members.

\subsection{Addressing Environmental Challenges}

Recent European and international reports attest to the fact that water bodies globally have become seriously polluted over the past 50 years. In Ireland, in the early 1990s, some 500 rivers were in a 'pristine' condition, but only 20 rivers can be described as such today [20]. The eutrophic status of many Irish lakes provides further evidence of deteriorating water quality.

The community-owned group water scheme sector has been on a drinking water source protection journey over the past 20 years, led by the NFGWS. The National Source Protection pilot project completed in 2010 highlighted the importance of understanding catchments in order to protect drinking water quality at source catchment level [73]. In 2012, the NFGWS partnered with the Irish Geological Survey of Ireland and with Dundalk Institute of Technology in the delineation of catchments/zones of contribution (ZOC) on all privately sourced community-owned group water schemes. With grant assistance from the Irish Government and on-site co-operation from local GWS personnel, completed catchment/ZOC maps and technical overview reports were presented individually to each GWS committee/board of management. Building on these reports, in 2018, source protection pilot projects commenced on ten schemes of different scale and size to develop and implement Integrated Source Protection Plans (ISPPs). Arising from these pilot projects, the NFGWS produced a Framework Document and a Guidance Document to assist schemes in the process of source protection planning and the implementation of measures following similar processes being utilised to implement the Water Framework Directive in Ireland [74].

Through the implementation of ISPPs, community-owned water supplies are uniquely placed and equipped to also help deliver on biodiversity enhancement as well as on the wider objectives of the Water Framework Directive [1] and the Habitats Directive [75]. Many source protection measures (e.g., the creation of vegetative buffers around water sources and alongside river/water courses), include a significant number of co-benefits to enhance local ecosystems and the wider environment by providing habitat and protecting food sources.

As the implementation of such measures require buy-in from farmers and from nonfarm households, a complete 'community effort' is needed, mobilising all stakeholders living and working within each catchment. As the scientific evidence is already available to identify significant pressures impacting water supplies, the task at community level is to build awareness about what the science is indicating and to build awareness about how local behaviour can effect change for better or for worse. Once citizens are made aware of how their everyday lives/working situations impact on their immediate environment and on their drinking water source, the NFGWS experience is that they will be more easily 
persuaded to change their ways and to see the need to respect their environment and contribute to the restoration of nature [76].

The vast majority of farmers and non-farm householders in their catchment area are actually members or shareholders of the scheme/co-operative. To become members, they each made sizeable contributions and, therefore, would always wish to protect their investment. Communities fully appreciate the importance of the group water scheme to the quality of their lives and to their business enterprises, and, as a result are more likely to engage, if requested, in any plans to protect or improve that water supply.

While it will take a long time to reap the water quality benefits of the implementation of these source protection measures, there are some promising signs emerging already. Water quality in a lake in the northeast of the country, Kilcorran Lough, County Monaghan, has been recently reclassified by the EPA, changing from a 'moderate' to 'good' status [77]. The lake is the drinking water source for Aughnashalvey GWS, which has implemented a series of source protection measures in its source catchment, with the co-operation of the local farming community. These measures may have made a significant contribution to the restoration of water quality in the lake.

\subsection{Education and Research}

In Ireland, besides direct engagement with adults, there are in excess of 200 primary schools located in areas of group water scheme supplies. Recognising the potential benefits of children bringing positive environmental messages home [78], 'Educating Communities Through Schools' is recognised by the NFGWS as a priority for any communityowned drinking water supply. As part of the first National Source Protection Pilot Project, dedicated classroom resources were developed for both national and secondary school pupils [79]. The reaction to the programme has been universally positive, from teachers and pupils alike and, as a measure of a practical benefit of the course, schemes have seen improvements in water conservation where pupils bring that message home.

By widening the focus of such curriculums to include dedicated lessons on biodiversity and climate action, the NFGWS is confident that CoDWS can provide positive guidance on these issues. It will also strengthen social cohesion through involvement in a collaborative community activity.

NFGWS initiatives, such as 'I've planted a tree and my garden is pesticide free' - where over 8000 school children have been given a tree to plant at home - and 'Let it Bee' — which raises community awareness around the dangers of pesticides to water quality and biodiversity-shows that innovative methods, outside of the classroom curriculum, can also help educate families on important environmental issues [80].

eLearning technology is providing key educational tools in regard to water and other environmental issues [81] and is an area with significant growth potential [82]. This is exemplified by the online water conservation tool created by the NFGWS to help householders calculate their water usage and provide them with conservation tips [83], not to mention the NFGWS's migration to delivering training services in an online fashion due to the onset of the Covid-19 pandemic.

In terms of academic research, the Irish group water scheme sector has been a much relied upon resource; its approachability, access to historical water quality data, and accessible sampling points being just some of the influencing factors. Published research includes topics such as the presence of veterinary drugs in groundwater [84], sustainable development [45], and drinking water source protection [4].

As stated in its Terms of Reference, ACOWAS-EU will seek to maximise the potential for member CoDWS to learn from each other, thus providing a knowledge-transfer vehicle that will be of importance to all those interested in issues relevant to the sector.

\subsection{Community Involvement}

A renewed community-statutory partnership is essential for better outcomes for communities [85]. Communities can best be motivated to engage in environmental action 
if they recognise threats to their immediate environment or to their way of life. Quality drinking water is perhaps the most important requirement to healthy living and citizens respond positively to requests from their local scheme for sustained actions to protect a water source catchment. It is precisely because they are stakeholders in their own source catchment area that citizens in community-owned water supplies are amenable to arguments about the need for environmental protection.

As evidenced in this case study, having raised awareness about the need to care for that environment, communities are more open to making changes that can benefit drinking water quality and the local environment, along with the associated economic benefits of both. Activating the power of (and devolving power to) communities require robust community development and local development infrastructure, assisted and supported by both central and local government [85]. A robust infrastructure will provide a framework for community support that will improve people's lives and community well-being, resilience, and capacity to respond to emerging challenges [85]. The CoDWS sector, with its co-operative roots and ethos, is a critical stakeholder in this regard.

In recent years, the community basis of group water schemes has been shown to provide a distinct advantage in actively engaging communities by promoting environmental consciousness, including biodiversity protection and enhancement and climate action. Engaging communities in the development of catchment to tap Water Safety Plans in readiness for implementation of the recast Drinking Water Directive should also be a priority for every CoDWS.

\section{Conclusions}

Co-operative models must fit with the needs of contemporary society, culture, and economy. Indeed, sustainable management necessitates an awareness of the complexity of the different systems involved (social, biophysical, economic, etc.) and of their interactions [86]. Creativity and flexibility is needed when developing and adapting models, while ensuring alignment with the seven core co-operative principles. The community-owned drinking water supply movement have shown an ability to achieve this throughout their existence and provide a perfect platform for the delivery of essential local services. The co-operative model, based on relationships of trust, also provides an alternative in the debate between the virtues of public supply vs. private management [64].

While this paper has shone a light on the co-operative model within CoDWS across the ACOWAS-EU region, there is scope for further analysis of these structures in the regions and further afield. Indeed, as the concept of water resources as a common pool resource-or common good (e.g., [87-90]), which has a long history in water management [91]—gains traction, the formation of the CoDWS and associated learnings from ACOWAS-EU have a role in providing an interesting perspective to this debate.

A vibrant community-owned drinking water sector rooted in the principles of the co-operative movement exist in many European countries today. While established initially out of basic need, their evolution demonstrates the potential within the sector, not solely to provide basic infrastructure and services, but to also add value to that service. Despite the challenges that all small water supplies must overcome to ensure compliance with the Drinking Water Directive, where investment has been made, the sector has demonstrated an ability to adapt and provide services to the highest standard.

Given the essential drinking water service provided by the sector, community-owned drinking water supplies must ensure ongoing investment in their assets and governance structure. Charging models for services need to be reflective of this to ensure sustainability into the future. State support, where available, should be utilised and where not, community-owned drinking water supplies and their representative organisations should work collaboratively with the state and governing bodies to secure financial assistance for such an essential service.

Better decisions are made if the people affected are involved in the process and feel a sense of ownership over outcomes affecting their lives [85]. The community-owned 
drinking water sector is embedded in rural life and the rural economy, supporting people, manufacturing, farming, and off-farm industries, such as food production, etc. It plays an important factor in the success of rural tourism initiatives. It gives life to communities. Community-owned water supplies should therefore be supported to promote such activities, which, with its voluntary ethos, its record of community activism and its success in reducing water wastage, is well placed to support and sustain an expanded rural economy. In particular, the locally-based and collective community approach provided by community-owned water supplies provides an obvious vehicle to promote the behavioural change that is required if we are to overcome the environmental challenges identified as a crisis by the Irish parliament.

The establishment of ACOWAS-EU will greatly help create awareness of the communityowned water supply sector within Europe and it is hoped that the Alliance will equally be recognised by policy makers across the continent when consulting on policy issues relevant to the rural water sector. However, in order for the Alliance to be recognised, consideration should be given to formalising its structure. Given the Alliance provides a vehicle to represent the agreed collective views of the sector on policy issues, for example, any future structure should seek to build on the co-operative ethos and structure of the parent organisations.

Author Contributions: Conceptualization, B.D. and B.M.D.; formal analysis, B.D. and B.M.D.; investigation, B.D. and B.M.D.; writing—original draft preparation, B.D. and B.M.D.; writing-review and editing, B.D.; project administration, B.D. All authors have read and agreed to the published version of the manuscript.

Funding: The research paper has received no funding.

Institutional Review Board Statement: Not applicable.

Informed Consent Statement: Not applicable.

Data Availability Statement: No new data were created or analyzed in this study. Data sharing is not applicable to this article.

Acknowledgments: The authors would like to express great gratitude to Darragh Walshe, of the Irish Co-operative Organisation Society; each of the umbrella representative bodies within the various regions of ACOWAS-EU (namely OÖ Wasser, Danske Vandvaerker, SVOSK, and COXAPO); and Suzanne Linnane, of Dundalk Institute of Technology for their help and guidance in putting this paper together.

Conflicts of Interest: The authors declare no conflict of interest.

\section{References}

1. European Commission. Directive 2000/60/EC of The European Parliament and of The Council. Off. J. Eur. Communities 2000, 327, 7-8.

2. Council of the European Union. Council Directive 98/83/EC of 3 November 1998 on the quality of water intended for human consumption. Off. J. L 1998, 330, 32-54.

3. European Parliament, Council of the European Union. Directive (EU) 2020/2184 of the European Parliament and of the Council of 16 December 2020 on the quality of water intended for human consumption (recast) (Text with EEA relevance). Off. J. L. 2020, 435, 1-62.

4. Rolston, A.; Linnane, S. Drinking Water Source Protection for Surface Water Abstractions: An Overview of the Group Water Scheme Sector in the Republic of Ireland. Water 2020, 12, 2437. [CrossRef]

5. European Federation of National Associations of Water Services (EurEau). The Governance of Water Services in Europe. 2020. Available online: https://www.eureau.org/resources/publications/5268-the-governance-of-water-services-in-europe-2020 -edition-2/ file (accessed on 27 September 2021).

6. World Health Organization (WHO). Small-Scale Water Supplies in the Pan-European Region. 2011. Available online: https: //www.euro.who.int/_data/assets/pdf_file/0018/140355/e94968.pdf (accessed on 27 September 2021).

7. World Bank Group. Sustainability Assessment of Rural Water Service Delivery Models: Findings of a Multi-Country Review. World Bank, Washington, DC. @ World Bank. 2017. Available online: https:/ / openknowledge.worldbank.org/handle/10986/27 988 (accessed on 27 September 2021). 
8. Environmental Protection Agency USA (EPA). Focus on Private Water Supplies 2019. 2021. Available online: https:/ / www.epa.ie/ publications / compliance--enforcement/drinking-water/annual-drinking-water-reports / focus-on-private-water-supplies-20 19.php (accessed on 27 September 2021).

9. Wikiland. History of the Cooperative Movement. 2021. Available online: https://www.wikiwand.com/en/History_of_the_ cooperative_movement\#/google_vignette (accessed on 27 September 2021).

10. Carrell, S.; Strike Rochdale from the record books. The Co-op began in Scotland. The Guardian. 2007. Available online: https:/ / www.theguardian.com/business/2007/aug/07/retail.uknews (accessed on 27 September 2021).

11. International Co-Operative Alliance. Milestones in ICA's journey. 2021. Available online: https://www.ica.coop/en/ cooperatives/history-cooperative-movement\#milestones-in-ica-journey (accessed on 27 September 2021).

12. Van Opstal, W. International Encyclopedia of Civil Society; Springer Science + Business Media: New York, NY, USA, 2010.

13. Madrigal Sanchez, A.M. Community Based Water Utilities. Master's Thesis, University of Natural Resources and Life Sciences, Vienna, Austria, 2019.

14. Romano, G. Le Cooperative Idriche in Italia e in Europa. Evoluzione, Assetti di Governance, Performance e Prospettive della Gestione delle Community-Owned Water Supplies; Franco Angeli: Milan, Italy, 2019.

15. Arvonen, V.; Kibocha, S.N.; Katko, T.S.; Pietilä, P. Features of Water Cooperatives; A Comparative Study of Finland \& Kenya. Public Work. Manag. Policy 2017, 22, 356-377. [CrossRef]

16. OÖ Wasser. The OÖ WASSER Idea. 2021. Available online: https://www.ooewasser.at/de/ueber-uns/die-ooe-wasser-idee.html (accessed on 27 September 2021).

17. Etongo, D.; Fagan, H.; Kabonesa, C.; Asaba, R. Community-Managed Water Supply Systems in Rural Uganda: The Role of Participation and Capacity Development. Water 2018, 10, 1271. [CrossRef]

18. International Co-Operative Alliance. International Co-Operative Alliance World Congress; ICA: Manchester, UK, 1995.

19. National Federation of Group Water Schemes (NFGWS). Annual Report 2020 -National Federation of Group Water Schemes. 2021. Available online: https://nfgws.ie/wp-content/uploads/2021/04/Annual-Report-2020.pdf (accessed on 27 September 2021).

20. EPA. Ireland's Environment-An Integrated Assessment 2020. 2020. Available online: https://www.epa.ie/publications/ monitoring--assessment/assessment/state-of-the-environment/irelands-environment-2020---an-assessment.php (accessed on 27 September 2021).

21. The Intergovernmental Science-Policy Platform on Biodiversity and Ecosystem Services (IPBES). Global Assessment Report on Biodiversity and Ecosystem Services of the Intergovernmental Science-Policy Platform on Biodiversity and Ecosystem Services; IPBES secretariat: Bonn, Germany, 2019; 1148p, Available online: https:/ /ipbes.net/global-assessment (accessed on 27 September 2021). [CrossRef]

22. RTE. Ireland Becomes Second Country to Declare Climate Emergency. 2019. Available online: https://www.rte.ie/news/ environment/2019/0509/1048525-climate-emergency / (accessed on 27 September 2021).

23. Laaninen, T. Revision of the Drinking Water Directive. EU Legislation in Progress. Briefing Document to the European Parliament. 2021. Available online: https://www.europarl.europa.eu/RegData/etudes/BRIE/2018/625179/EPRS_BRI(2018)625179_EN.pdf (accessed on 27 September 2021).

24. World Bank. Water and Wastewater Services in the Danube Region: Austria Country Note. Washington, DC. (C) World Bank. 2015. Available online: https:/ / openknowledge.worldbank.org/handle/10986/22137 (accessed on 27 September 2021).

25. IG Wassergenossenschaften Südburgenland. About Us; Members. 2021. Available online: https://www.wassergenossenschaften. at/ (accessed on 27 September 2021).

26. Dachverband Salzburger Wasserversorger (DSWV). About Us. 2021. Available online: https://www.wasserversorger.at/wirueber-uns.html (accessed on 27 September 2021).

27. Steirischer Wasserversorgungsverband (StWV). Supply and System Statistics. 2017. Available online: https://www.stwv.at/ index.php?id=54 (accessed on 27 September 2021).

28. Dansk Vand- og Spildevandsforening (DANVA). Drinking Water and Wastewater Service Management. 2016. Available online: https: / / www.danva.dk/om-danva/the-danish-water-sector/drinking-water-and-wastewater-service-management/ (accessed on 27 September 2021).

29. Danske, V. Who We Are. 2020. Available online: https:/ /www.danskevv.dk/om-os/hvem-er-vi/ (accessed on 27 September 2021).

30. Pellervo. Co-Operation in Finland. 2021. Available online: https://pellervo.fi/en/english/cooperation-finland/ (accessed on 27 September 2021).

31. Luukkonen, H. Water Cooperatives, Municipal Water Utilities and Municipalities; Association of Finnish Local and Regional Authorities: Helsinki, Finland, 2013.

32. Juuti, P.S.; Katko, T.S. From a Few to All—Long Term Development of Water and Sanitation Services in Finland; Tampere University Press: Tampere, Finland, 2004.

33. Takala, A.J.; Arvonen, V.; Katko, T.S.; Pietilä, P.E.; Åkerma, M.W. The evolving role of water co-operatives in Finland. Int. J. Co-Oper. Manag. 2011, 5, 11-19.

34. Suomen Vesihuolto-Osuuskunnat Ry (SVOSK). Rules of the Association. 2021. Available online: https://svosk.fi/svosk-3/ yhdistyksen-saannot/ (accessed on 27 September 2021).

35. Sanchez, A.M.M. Community Owned Water Supply Systems-Case of Studies in COXAPO (Galicia, Spain). 2021. Available online: https:/ / abstracts.boku.ac.at (accessed on 27 September 2021). 
36. European Commission. Sustainable Solutions for Very Small Water Supplies. Available online: https:/ / webgate.ec.europa.eu/ life/publicWebsite/project/details/3860 (accessed on 27 September 2021).

37. Campo Galego. What Will Happen to the Conflict of Local Water Supplies? 2017. Available online: https://www.campogalego. es / que-sucedera-con-el-conflicto-de-las-traidas-vecinales-de-agua / (accessed on 27 September 2021).

38. Comunidad Xeral de Augas de Galicia (COXAPO). 2021. Available online: https:/ / www.coxapo.com/ (accessed on 1 March 2021).

39. Pietilä, P.; Arvonen, V.; Katko, T. Role of Water Cooperatives in Water Service Production—Lessons from Finland and Denmark. 2020. Available online: https://www.researchgate.net/publication/344430353_Role_of_Water_Cooperatives_in_Water_Service_ Production_-Lessons_from_Finland_and_Denmark (accessed on 27 September 2021).

40. Doyle, P. Civilising Rural Ireland; Manchester University Press: Manchester, UK, 2019.

41. Irish Times. Agricultural Co-Ops Caught in a Time Warp. 2010. Available online: https://www.irishtimes.com/business/ agricultural-co-ops-caught-in-a-time-warp-1.667956 (accessed on 27 September 2021).

42. Plunkett Institute. Plunkett Institute. 2021. Available online: https:/ / plunkettinstitute.ie/ (accessed on 27 September 2021).

43. MacDonald, B. Lakeland Dairies \& the Triumph of Co-operation 1896-1996. In Lakeland Dairies E the Triumph of Co-Operation 1896-1996; Lakeland Dairies: Monaghan, Ireland, 1996; p. 42.

44. NFGWS. Ireland's Community-Owned Rural Water Sector-Background and Early Development. 2019. Available online: https://nfgws.ie/wp-content/uploads/2019/06/Background-and-early-development_pdf (accessed on 27 September 2021).

45. Bresnihan, P.; Hesse, A.; White, J.M. Learning from Group Water Schemes: Community Infrastructures for Sustainable Development, EPA, Report No.364. 2021. Available online: https:/ / www.epa.ie/publications/research/water/Research_Report_364.pdf (accessed on 27 September 2021).

46. Deane, B. An Evolution of Group Water Schemes in the Republic of Ireland. Master's Thesis, University College Dublin, Dublin, Ireland, 2003.

47. Brady, J.; Gray, N.F. Group Water Schemes in Ireland-Their role within the Irish Water Sector. Eur. Water 2010, $29,39-58$.

48. NFGWS. Future Group Water Scheme Investment Needs as identified by the NFGWS. 2021. Available online: https://nfgws.ie/wpcontent/uploads /2021/10/NFGWS-Submission-to-Tobin-Future-Investment-Needs-15-07-21.pdf (accessed on 4 November 2021).

49. EPA. Drinking Water Quality in Public Supplies 2019. Available online: https://www.epa.ie/publications/compliance-enforcement/drinking-water/annual-drinking-water-reports/DW-Quality-in-Public-Supplies-2019_web.pdf (accessed on 4 November 2021).

50. NFGWS. Transformation of the GWS Sector under the Rural Water Programme. 2019. Available online: https://nfgws.ie/wp-content/ uploads /2019/06/Transformation-under-the-Rural-Water-Programme_ater-Programme.pdf (accessed on 27 September 2021).

51. Irish Times. Dirty Drinking Water. 2000. Available online: https://www.irishtimes.com/opinion/dirty-drinking-water-1.1120913 (accessed on 27 September 2021).

52. Houses of the Oireachtas. Dáil Éireann Debate-Tuesday, 16 May 1995. Volume 452, No. 8. 1995. Available online: https: / / www.oireachtas.ie/en/debates/debate/dail/1995-05-16/17/ (accessed on 27 September 2021).

53. NFGWS. 2001 NFGWS Annual Reports. 2002. Available online: https://nfgws.ie/wp-content/uploads/2016/09/2001 AnnualReportfinal.pdf. (accessed on 27 September 2021).

54. European Court of Justice. Commission of the European Communities V Ireland Case C-316/00. 2002. Available online: https: / / eur-lex.europa.eu/legal-content/EN/TXT/PDF/?uri=CELEX:62000CJ0316\&from=HR (accessed on 27 September 2021).

55. European Commission. (n.d.). Drinking Water-Small Water Supplies. Available online: https:/ / ec.europa.eu/environment/ water/water-drink/small_supplies_en.html (accessed on 27 September 2021).

56. Organisation for Economic Co-operation and Development (OECD). Financing Water Supply Sanitation and Flood ProtectionCountry Fact Sheets. 2020. Available online: https:/ / www.oecd.org/publications/financing-water-supply-sanitation-and-floodprotection-6893cdac-en.htm (accessed on 27 September 2021).

57. European Commission. Reporting Requirements and Synthesis Reports. 2016. Available online: https://ec.europa.eu/ environment/water/water-drink/reporting_en.html (accessed on 27 September 2021).

58. The Danish Environmental Protection Agency. (n.d.) The Danish Action Plan for Promotion of Eco-Efficient TechnologiesDanish Lessons. Available online: https://eng.ecoinnovation.dk/media/mst/8051461/Vandforsyning_artikel.pdf (accessed on 27 September 2021).

59. Jørgensen, L.F.; Stockmarr, J. Groundwater monitoring in Denmark: Characteristics, perspectives and comparison with other countries. Hydrogeol. J. 2009, 17, 827-842. [CrossRef]

60. Finnish Institute of Health \& Welfare. Environmental Health—Drinking Water. 2021. Available online: https://thl.fi/en/web/ environmental-health/water/drinking-water (accessed on 27 September 2021).

61. Government of Ireland. Group Water Schemes and Rural Water Issues. 2020. Available online: https://www.gov.ie/en/ publication/a524a-group-water-schemes-and-rural-water-issues/\#rural-water-programme (accessed on 27 September 2021).

62. Scott, S. Abolition of Domestic Water Charges in Ireland. 2003. Available online: https://www.esri.ie/system/files?file=media / file-uploads/2015-07/JACB200850.pdf (accessed on 27 September 2021).

63. Bresnihan, P. The bio-financialization of Irish Water: New advances in the neoliberalization of vital services. Utilities Policy 2016, 40, 115-124. [CrossRef]

64. Rodriguez-Sanchez, C.; Schuitema, G.; Claudy, M.; Sancho-Esper, F. How trust and emotions influence policy acceptance: The case of the Irish water charges. Br. J. Soc. Psychol. 2018, 57, 610-629. [CrossRef] [PubMed] 
65. Government of Ireland. Report of the Joint Committee on the Future Funding of Domestic Water Services. 2017. Available online: https://www.gov.ie/en/publication/ca32e-report-of-the-joint-committee-on-the-future-funding-of-domestic-water-services / (accessed on 27 September 2021).

66. Department of Housing Local Government and Heritage (DHLGH). Circular L2/18 - Subsidy towards the Operational Costs of Group Water Schemes Providing Water for Domestic Use. 2018. Available online: http://www.housing.old.gov.ie/water/waterservices/rural-water-programme/circular-1218-subsidy-towards-operational-costs-group (accessed on 27 September 2021).

67. Linnane, S.; Jordan, S.; McCarthy, V.; Jennings, E.; Carson, A.; Sweeney, N.; Wynne, C.; McDonald, B. National Source Protection Pilot Project Final Report 2005-2010; National Rural Water Services Committee: Dublin, Ireland, 2011.

68. Clinch, J.P.; Pender, A. You don't miss the water 'til the well runs dry-An Inquiry into the factors influencing the failure of domestic water charges in Ireland. Econ. Soc. Rev. 2019, 50, 369-389.

69. Moroney, D.A.; Carroll, B.; McCarthy, D.O. Go Co-Op: Cases of Recent Irish Co-Operative Start-Ups; Centre for Co-Operative Studies University College Cork: Cork, Ireland, 2017.

70. NFGWS. Group Water Scheme Rationalisation and Amalgamation Strategy 2016-2018. 2016. Available online: https://nfgws.ie/ group-water-scheme-rationalisation-and-amalgamation/ (accessed on 27 September 2021).

71. Murtagh, D.A.; Kelly, D.E. Agricultural Cooperatives, Innovation Intermediaries and the Institutional Environment: Learnings from the Irish Dairy and Beef Sectors; UCD: Dublin, Ireland, 2021.

72. ICOS Limited. What Is a Co-Operative? 2020. Available online: http://icos.ie/starting-a-co-op/what-is-a-co-op/ (accessed on 27 September 2021).

73. National Rural Water Monitoring Committee. An Action Plan for Rural Drinking Water Quality; National Rural Water Monitoring Committee: Dublin, Ireland, 2003.

74. NFGWS. The NFGWS and Source Protection. 2021. Available online: https://nfgws.ie/the-nfgws-and-source-protection/ (accessed on 27 September 2021).

75. Council of the European Union. Council Directive 92/43/EEC of 21 May 1992 on the conservation of natural habitats and of wild fauna and flora. Off. J. L 1992, 206, 7-50.

76. Agriland. Farmers Lead the Way in Group Water Scheme Project. 2021. Available online: https://www.agriland.ie/farmingnews / farmers-lead-the-way-in-group-water-scheme-project/ (accessed on 27 September 2021).

77. NFGWS. Kilcorran Lough's Restoration Shows What Is Possible. 2021. Available online: https://nfgws.ie/kilcorran-loughsrestoration-shows-whats-possible/ (accessed on 27 September 2021).

78. Gilleran, S.C.; Short, A.; Linnane, S. $\mathrm{H}_{2} \mathrm{O}$ Heroes: Adding value to an environmental education outreach programme through intergenerational learning. Ir. Educ. Stud. 2021, 1-22. [CrossRef]

79. NFGWS. All About Water-Water Education for Primary Schools. 2021. Available online: https://nfgws.ie/3360-2/ (accessed on 27 September 2021).

80. Eolas. Group Water Schemes Leading Efforts to Protect the Environment. 2021. Available online: https:/ /www.eolasmagazine. ie/group-water-schemes-leading-efforts-to-protect-the-environment/ (accessed on 27 September 2021).

81. Kossieris, P.; Panayiotakis, A.; Tzouka, K.; Gerakopoulou, P.; Rozos, E.; Makropoulos, C. An eLearning Approach for Improving Household Water Efficiency. Procedia Eng. 2014, 89, 1113-1119. [CrossRef]

82. Dlima, N.; Prabhu, A.; Joseph, J.; Khan, S. Novel Approach in E-Learning to Imbibe Environmental Awareness. Int. J. Comput. Eng. Technol. 2013, 4, 166-171.

83. NFGWS. Water Saving Calculator. 2020. Available online: https://nfgws.ie/water-saving-calculator/ (accessed on 27 September 2021).

84. Mooney, D.; Richard, K.G.; Danaher, M.; Grant, J.; Gill, L.; Mellander, P.-E.; Coxon, C.E. An analysis of the spatio-temporal occurrence of anthelmintic veterinary drug residues in groundwater. Sci. Total Environ. 2021, 769, 144804. [CrossRef]

85. Government of Ireland. Sustainable, Inclusive and Empowered Communities 2019-2024. 2019. Available online: https: / assets.gov. ie/26890 /ff380490589a4f9ab9cd9bb3f53b5493.pdf (accessed on 5 November 2021).

86. Cumming, G.S.; Olsson, P.; Chapin, F.S.; Holling, C.S. Resilience, Experimentation, and Scales Mismatches in Social-Ecological Landscapes. Landsc. Ecol. 2013, 28, 1139-1150. [CrossRef]

87. Bieler, A.; Jordan, J. Commodification and 'the commons': The politics of privatising public water in Greece and Portugal during the Eurozone crisis. Eur. J. Int. Relat. 2018, 24, 934-957. [CrossRef]

88. de Jongh, M. Public Goods and the Commons: Opposites or Complements? Political Theory 2021, 49, 774-800. [CrossRef]

89. European Water Movement. European Water Movement-Protecting Water as a Commons. 2021. Available online: http:// europeanwater.org (accessed on 27 October 2021).

90. Paerregaard, K.; Andersen, A.O. Moving beyond the commons/commodity dichotomy: The socio-political complexity of Peru's water crisis. Water Altern. 2019, 12, 459-469.

91. Herrfahrdt-Pähle, E.; Scheumann, W.; Houdret, A.; Dombrowsky, I. Freshwater as a global commons: International governance and the role of Germany. Discussion paper. In Deutsches Institut für Entwicklungspolitik; German Development Institute: Bonn, Germany, 2019. 